\title{
MANFAAT DOKUMENTASI KEPERAWATAN
}

\author{
Syifahanun Septiani
}

\author{
Syifahanun.s@yahoo.co.id
}

\begin{abstract}
Abstrak
Keperawatan adalah bentuk pelayanan profesional berupa pemenuhan kebutuhan dasar yang diberikan kepada individu yang sehat maupun sakit yang mengalami gangguan fisik, psikis, dan sosial agar dapat mencapai derajat kesehatan yang optimal. Bentuk pemenuhan kebutuhan dasar dapat berupa meningkatkan kemampuan yang ada pada individu, mencegah, memperbaiki, dan melakukan rehabilitasi dari suatu keadaan yang di persepsikan sakit oleh individu (Nursalam, 2008). Cara pandang dasar dalam melihat suatu permasalahan dalam suatu disiplin ilmu disebut dengan paradigma. Paradigma juga sering diartikan sebagai suatu perangkat bantuan yang memiliki nilai dan sangat menentukan bagi penggunanya untuk dapat memiliki pola dan cara pandang dasar dalam melihat, memikirkan, menentukan makna serta menyikapi dan memilih tindakan dalam menyelesaikan masalah kehidupan manusia (Poerwanto, 2007).

Perkembangan ilmu Pediatri ini tidak dapat dipisahkan dari kemajuan ilmu pengetahuan dan teknologi karena lebih dari seabad yang lalu ilmu pediarti muncul sebagai kekhususan dalam menanggapi meningkatan kasadaran bahwa problem kesehatan anak berbeda dengan orang dewasa dan bahwa respon anak terhadap sakit dan stres berdeda beda sesuai dengan umur. Pediarti berkenaan dengan kesehatan bayi, anak remaja, pertumbuhan, perkembangan dan kesempatannya untuk mencapai ptensi penuh sebagai orang dewasa (Hidayat, 2005).

Dokumentasi perawatan anak merupakan dokumentasi kelompok khusus dalam proses keperawatan yang di tulis berdasarkan kondisi anak berusia mulai dari 28 hari, sampai 18 tahun yang harus dicatat secara akurat, konsisten, dan komprehensif. Dalam hal ini perawat sangat berperan penting dalam mendokumentasikan proses keperawatan pada tatanan keperawatan anak . pada makalah ini akan dibahas tentang dokumentasi asuhan keperawatan pada tatanan keperawatan anak, dimana pendekatan yang digunakan adalah 5 tahap proses keperawatan yaitu meliputi pengkajian, diagnosa, perencanaan, pelaksanaan dan evaluasi (Poerwanto,2007)
\end{abstract}

Kata kunci : Keperawatan, dokumentasi, manfaat, dan perawat

\section{Latar belakang}

Dokumentasi keperawatan adalah informasi tertulis tentang status dan perkembangan kesehatan pasien serta semua kegiatan asuhan keperawatan yang dilakukan oleh perawat (Koesier, dkk, 2010). Dokumentasi keperawatan merupakan media komunikasi yang efektif antar profesi dalam suatu tim pelayanan kesehatan yang bertujuan untuk melihat dan menganalisa perkembangan kondisi pasien, untuk perencanaan perawatan pasien, sebagai indicator kualitas pelayanan kesehatan, sumber data untuk penelitian dalam pengembangan keperawatan, pertanggung gugatan pelaksanaan asuhan keperawatan serta sebagai sarana pendidikan bagi mahasiswa keperawatan ( Manurung, 2011) 
Dalam memberikan asuhan keperawatan kepada pasien, perawat harus menyadari pentingnya dokumentasi asuhan keperawatan kepada pasien, sebagai pertanggung jawaban dan pertanggung gugatan pelaksanaan asuhan keperawatan serta untuk menjamin pelaksanaan asuhan dapat berlangsung kontinue dan akurat. Dengan demikian diharapkan asuhan keperawatan yang diberikan kepada pasien dapat optimal dan berkualiatas.

\section{Metode}

Artikel ilmiah ini menggunakan metode membaca dan menganalisa, kajian dari beberapa referensi seperti, jurnal, buku dan e-book. dan juga membandingkan beberapa jurnal yang berhubungan dengan kemampuan perawat dalam memberikan Keselamatan dan kesehatan kerja. Dari analisi berbagai sumber digunakan Untuk mengetahui manfaat dokumentasi keperawatan.

\section{Hasil}

Komponen Dokumentasi Keperawatan

Peran perawat sebagaimana kita ketahui adalah salah satunya dokumentasi sebagai pertanggungjawaban keperawatan, Akan tetapi akhir-akhir ini tanggung jawab perawat tehadap dokumentasi sudah berubah, Akibatnya, isi dan fokus dari dokumentasi telah dimodifikasi. Oleh karena perubahan tersebut ,maka perawat perlu menyusun suatu model dokumentasi yang baru, lebih efisien dan lebih bermakna dalam pencatatan dan penyimpanannya. Komponen yang digunakan mencakup tiga aspek :

1. Komunikasi

Kapan saja perawat melihat pencatatan kesehatan, perawat memberi dan menerima pendapat dan pemikiran, Untuk lebih efektif penyaluran ide tersebut, perawat memerlukan keterampilan dalam menulis, Dalam kenyataannya, dengan semakin kompleknya pelayanan keperawatan dan peningkatan kualitas keperawatan, perawat tidak hanya dituntut untuk meningkatkan mutu pelayanan, tetapi dituntut untuk dapat mendokumentasikan secara benar. Keterampilan dokumentasi yang efektif memungkinkan perawat untuk mengkomunikasikan kepada tenaga kesehatan lainnya dan menjelaskan apa yang sudah, sedang dan yang akan dikerjakan oleh perawat. Kegunaan komunikasi :

a. Dapat digunakan ulang untuk keperluan yang bermanfaat

b. Mengkomunikasikan kepada tenaga perawat lainnya dan tenaga kesehatan apa yang telah terjadi dan diharapkan terjadi

c. Manfaat dan data pasien yang akurat dapat dicatat

d. Penulisan catatan menggambarkan sesuatu yang kreatif

2. Proses Keperawatan 
Perawat memerlukan keterampilan dalam mencatat proses keperawatan, Pencatatan proses keperawatan merupakan metode yang tepat untuk pengambilan keputusan yang sistematis, problemasolving dan riset lebih lanjut, format proses keperawatan merupakan kerangka atau dasar keputusan dan tindakan termasuk juga pencatatan hasil berfikir dan tindakan keperawatan. Dokumentasi adalah bagian integral proses, bukan sesuatu yang berbeda dari metode problema-solving. Dokumentasi proses keperawatan mencakup pengkajian, identifikasi masalah, perencanaan, tindakan, Perawat kemudian mengobservasi dan mengevaluasi respon klien terhadap tindakan yang diberikan dan mengkomunikasikan informasi tersebut kepada tenaga kesehatan lainnya. Pengkajian ulang dan evaluasi respon klien terhadap tindakan keperawatan medis dapat sebagai petunjuk dan kesinambungan dalam proases keperawatan,dan dapat sebagai petunjuk adanya perubahan dari setiap tahap. Pendokumentasian Proses Keperawatan yang efektif adalah :

- Penggunaan standar terminologi (Pengkajian, diagnosa, perencanaan, pelaksanaan dan evaluasi),

- Data yang bermanfaat dan relevan dikumpulkan kemudian dicatat sesuai dengan prosedur dalam catatan yang permanen,

- Diagnosa keperawatan disusun berdasarkan klasifikasi dan analisa data yang akurat,

- Rencana tindakan keperawatan ditulis dan dicatat sebagai bagian dari catatan yang permanen,

- Observasi dicatat secara akurat, lengkap dan sesuai urutan waktu,

- Evaluasi dicatat sesuai urutan waktunya, meliputi selama dirawat, dirujuk, pulang ataupun perubahan keadaan klien ,

- Rencana tindakan keperawatan yang direvisi berdasarkan hasil yang diharapkan dari klien

\section{Standar Dokumentasi}

Perawat memerlukan suatu standar dokumentasi untuk memperkuat pola pencatatan dan sebagai petunjuk atau pedoman praktik pendokumentasian dalam memberikan tindakan keperawatan. Fakta tentang kemampuan perawat dalam pendokumentasian ditunjukkan pada keterampilan menuliskan sesuai dengan standar dokumentasi yang konsisten, pola yang efektif, lengkap dan akurat.Penggunaan Pola Standar Dokumentasi yang Efektif meliputi :

- Kepatuhan terhadap aturan pendokumentasian yang ditetapkan oleh profesi atau pemerintah

- Standar profesi keperawatan dituliskan ke dalam catatan kesehatan, Data yang ada menjabarkan apa yang dilakukan pearawat, Perawat mempunyai kewenangan untuk merumuskan diagnosa keperawatan dan intervensi keperawatan terhadap respon klien terhadap masalah kesehatan klien actual dan resiko/potensial. 
- Peraturan tentang praktik keperawatan dapat dilihat pada catatan pelayanan kesehatan. Data yang tertulis menunjukan kegiatan perawat yang independen dan interdependen. Diagnosa keperawatan tidak secara khusus mempunyai ijin mendiagnosa masalah medis sebaliknya diagnosa medis tidak terdapat pada catatan keperawatan, tetapi diagnosa keperawatan dituliskan pada catatan, keperawatan.

- Pedoman akreditasi harus diikuti, Penekanan yang khusus pada data tentang kegiatan observasi dan evaluasi. Tahap pada proses keperawatan adalah dituliskannya data setiap klien pada waktu masuk rumah sakit sampai pulang.

\section{Pembahasan}

\section{A. Tujuan Dokumentasi Keperawatan}

Sebagai dokumen rahasia yang mencatat semua pelayanan keperawatan klien, catatan tersebut dapat diartikan sebagai suatu catatan bisnis dan hukum yang mempunyai banyak manfaat dan penggunaannya. Tujuan utama dari pendokumentasian adalah untuk :

1) Mengidentifikasi status kesehatan klien dalam rangka mencatat kebutuhan klien, merencanakan, melaksanakan tindakan keperawatan dan mengevaluasi tindakan,

2) Dokumentasi untuk penelitian, keuangan, hukum dan etika. Hal ini juga menyediakan :

- Bukti kualitas asuhan keperawatan

- Bukti legal dokumentasi sebagai pertanggungjawaban kepada klien

- Informasi terhadap perlindungan individu

- Bukti aplikasi standar praktik keperawatan

- Sumber informasi statistik untuk standar dan riset keperawatan

- Pengurangan biaya informasi

- Sumber informasi untuk data yang harus dimasukan

- Komunikasi konsep resiko tindakan keperawatan

- Informasi untuk murid

- Persepsi hak klien

- Dokumentasi untuk tenaga profesional dan tanggung jawab etik dan mempertahankan kerahasiaan informasi klien

- Suatu data keuangan yang sesuai

- Data perencanaan pelayanan kesehatan di masa akan datang,

Selain itu, dokumentasi juga diperlukan untuk :

- Menghindari kesalahan, tumpang tindih dan ketidaklengkapan informasi dalam asuhan keperawatan

- Terbinanya koordinasi yang baik dan dinamis antara sesama perawat atau pihak lain melalui komunikasi tulisan. 
- Meningkatkan efisiensi dan efektifitas tenaga keperawatan

- Terjaminnya kualitas asuhan keperawatan

- Perawat mendapat perlindungan secara hokum

- Memberikan data bagi penelitian, penulisan karya ilmiah, dan penyempurnaan standar asuhan keperawatan. ( Zaidin Ali, 1999)

B. Manfaat dan Pentingnya Dokumentasi Keperawatan

Dokumentasi keperawatan mempunyai makna yang penting bila dilihat dari berbagai aspek:

1) Hukum

Semua catatan informasi tentang klien merupakan dokumentasi resmi dan bernilai hukum, Bila terjadi suatu masalah (minconduct) yang berhubungan dengan profesi keperawatan, dimana perawat sebagai pemberi jasa dan klien sebagai pengguna jasa, maka dokumentasi diperlukan sewaktu-waktu, Dokumentasi tersebut dapat dipergunakan sebagai barang bukti di pengadilan, Oleh karena itu, data-data harus diidentifikasi secara lengkap, jelas, obyektif dan ditandatangani oleh tenaga kesehatan (perawat), tanggal dan perlunya dihindari adanya penulisan yang dapat menimbulkan interprestasi yang salah.

2) Jaminan Mutu (Kualitas Pelayanan )

Pencatatan data klien yang lengkap dan akurat, akan memberikemudahan bagi perawat dalam membantu menyelesaikan masalah klien dan untuk mengetahui sejauh mana masalah klien dapat teratasi dan seberapa jauh masalah baru dapat diidentifikasi dan dimonitor melalui catatan yang akurat, Hal ini akan membantu meningkatkan mutu pelayanan keparawatan.

\section{3) Komunikasi}

Dokumentasi keadaan klien merupakan alat "perekam" terhadap masalah yang berkaitan dengan klien, Perawat atau tenaga kesehatan lain akan bisa melihat catatan yang ada sebagai alat komunikasi yang dijadikan pedoman dalam memberikan asuhan keperawatan.

\section{4) Keuangan}

Dokumentasi dapat bernilai keuangan, Semua tindakan keperawatan yang belum, sedang dan telah diberikan dicatat dengan lengkap yang dapat dipergunakan sebagai acuan atau pertimbangan dalam biaya keperawatan bagi klien.

5) Pendidikan 
Dokumentasi keperawatan mempunyai nilai pendidikan ,karena isinya menyangkut kronologis dari kegiatan asuhan keperawatan yang dapat dipergunakan sebagai bahan atau referensi pembelajaran bagi siswa atau profesi keperawatan.

6) Penelitian

Dokumentasi keperawatan mempunyai nilai penelitian. Data yang terdapat didalamnya mengandung informasi yang dapat dijadikan sebagai bagian atau obyek riset dan pengembangan profesi keperawatan.

\section{7) Akreditasi}

Melalui dokumentasi keperawatan akan dapat dilihat sejauh mana peran dan fungsi perawat dalam memberikan asuhan keperawatan kepada klien. Dengan demikian akan dapat diambil kesimpulan tingkat keberhasilan pemberian asuhan keperawatan yang diberikan, guna pembinaan dan pengembangan lebih lanjut. Hal ini selain bermanfaat bagi peningkatan mutu sendiri, juga bagi individu perawat dalam mencapi tingkat kepangkatan yang lebih tinggi.

\section{Prinsip Dokumentasi Keperawatan}

Dokumentasi kepeawatan mempunyai 3 prinsip yaitu: Brevity, Legibility, dan Accuracy (Carpenitto, 1991) Prinsip-perinsip tersebut di atas dapat dijelaskan sebagai berikut:

1) Brevity

Dalam melakukan pendokumentasian setiap petugas/perawat harus brevity, Brevity sendiri adalah ringkas, jadi kita dalam mencatat isi dokumentasi keperawatan harus ringkas dan tidak perlu memasukan kata-kata atau kalimat yang tidak penting dan mempunyai makna yang tidak sesuai. Misal :

- Intervensi: Berikan cairan infus RL 4 tetes/menit (ringkas/brevity)

- Intervensi: Berikan cairan infus ringer laktat 4 tetes per menit karena di sarankan oleh dokter bedah yaitu dr. AA Sp.D. yang jaga sihf pagi.( tidak brevity).

Dengan menuliskan catatatan yang ringkas dan mengenai inti masalah maka catatan dokumentasi akan mudah di pahami dan tidak memakan ruang dalam lembar yang tersedia.

2) Legidibility

Legidibility yaitu dimana dalam penulisan/pencatatan dokumentasi keperawatan harus mudah dibaca dan di pahami oleh perawat lain atau profesi lain yang ikut dalam proses pendokumentasian. Misal : 
- Perawat harus menuliskan catatan yang jelas yang bisa dibaca dan di mengerti oleh perawat lain, dan tidak menuliskan istilah-istilah yang tidak di pahami oleh orang lain. Semisal ada istilah baru maka harus segera di diskusikan ke semua tim untuk menggunakan istilah tersebut.

3) Accuracy

Accuracy adalah sesuai dengan data yang ada pada klien. Jadi kita harus memasukan data pada dokementasi keperawatan harus benar dan sesuai dengan data baik identitas, laboratorium dan radiologi pada setiap klien. Ini adalah aspek yang sangat vital dan tidak boleh salah atau tertukar dengan klien lain. Misal :

- Dalam memasukan data pemberian obat perawat harus teliti dan tidak boleh salah, obat yang resepkan untuk Tn. A tidak boleh di berikan kepada Tn. C.

\section{Kesimpulan}

Dokumentasi proses keperawatan merupakan metode yang tepat untuk pengambilan keputusan yang sistematis, problem solving, dan riset lebih lanjut. Dokumentasi proses keperawatan mencakup pengkajian, identifikasi masalah, perencanaan, dan tindakan. Perawat kemudian Mengobservasi dan mengevaluasi respon klien terhadap tindakan yang diberikan, dan mengkomunikasikan informasi tersebut kepada tenaga kesehatan lainnya. pendokumentasian dalam memberikan tindakan keperawatan Perawat memerlukan sesuatu keterampilan untuk memenuhi standar dokumentasi. Standar dokumentasi adalah suatu pernyataan tentang kualitasn dan kwantitas dokumentasi yang dipertimnbangklan secara adekuat dalam suatu situasi tertentu. Standar dokumentasi berguna untuk memperkuat pola pencatatan dan sebagai petunjuk atau pedoman praktik. 


\section{Daftar Pustaka}

1. Simamora, R. (2009). Dokumentasi Proses Keperawatan.

2. Jasun. ( 2006). Aplikasi proses keperawatan dengan pendekatan , Nanda NIC, NOC dalam sistem informasi manajemen keperawatan . Disampaikan pada seminar di RSU Banyumas.Baturaden,11 Desember 2006.

3. Potter Patricia.(2005). Buku Ajar Fundamental keperawatan. EGC. Jakarta

4. Huda, Amin, dkk. 2015. Aplikasi Asuhan Keperawatan Berdasarakan Diagonosa Medis \& Nanda Nic-Noc, Edisi : 3. Jogjakarta : MediAction

5. Alimul Aziz. 2000. Pengantar Dokumentasi Proses Keperawatan. Jakarta: EGC

6. Nursalam. 2008. Proses Dan Dokumentasi Keperawatan. Edisi 2. Jakarta: Salemba Medika

7. Wahid Abd. 2012. Dokumentasi Proses Keperawatan. Yogjakarta: Nuha Medika

8. Hidayat,Aziz Alimul.2005.Pengantar Ilmu Keperawatan Anak 1.Jakarta,Salemba Medika.

9. Hutahaean, Serri. 2010.Konsep dan Dokumentasi Proses Keperawatan. Jakarta. Trans Info Media.

10. Koezier,dkk. 2010. Fundamental Keperawatan.Jakarta. EGC.

11. Poerwanto,2007.Konsep dalam Proses Keperawatan. Salemba Medika,Jakarta.

12. Nursalam,2007.Proses Keperawatan dan Dokumentasi : konsep dan praktik.jakarta. Salemba Medika. 